\title{
SEBARAN UKURAN HASIL TANGKAPAN DAN ASPEK REPRODUKSI IKAN SIDAT (Anguilla bicolor bicolor McClelland, 1844) DI PERAIRAN SEGARA ANAKAN, CILACAP
}

\author{
Isnani Herianti ${ }^{1}$ dan Duto Nugroho' \\ 1) Peneliti pada Balai Pengkajian Teknologi Pertanian, Ungaran-Jawa Tengah \\ 2) Peneliti pada Pusat Penelitian Pengelolaan Perikanan dan Konservasi Sumber Daya Ikan, Ancol-Jakarta \\ Teregistrasi I tanggal: 9 April 2010; Diterima setelah perbaikan tanggal: 3 September 2010; \\ Disetujui terbit tanggal: 5 Nopember 2010
}

\begin{abstract}
ABSTRAK
Penelitian biologi sumber daya ikan sidat telah dilakukan di perairan Segara Anakan, Cilacap dengan penekanan pada karakteristik biologi berdasarkan atas sebaran ukuran hasil tangkapan dan keragaan aktivitas reproduksi dalam populasi tersebut. Penampilan reproduksi dianalisis melalui pembuatan penampang lintang gonad dengan metode parafin dan pewarnaan hematoxylin ehrlicheosin terhadap contoh yang dianggap mewakili kelompok ukuran panjang. Hasil penelitian ini menunjukan bahwa sebaran frekuensi panjang mempunyai tipe bimodal dengan kecenderungan perbedaan kisaran ukuran berdasarkan atas musim. Rata-rata ukuran panjang hasil tangkapan berdasarkan atas musim menunjukan beda yang sangat nyata $(P<0,01)$. Keragaan aktivitas reproduksi sebagai bagian dari proses penentuan status pemanfaatan memperlihatkan kisaran pada tingkat belum teridentifikasi, belum berkembang sampai tingkat menuju matang gonad.
\end{abstract}

KATAKUNCI: $\quad$ segara anakan, ikan sidat, sebaran hasil tangkapan, aspek reproduksi

ABSTRACT: The size distribution and reproduction aspect on freshwater eel ikan sidat (Anguilla bicolor bicolor McClelland, 1844) in Segara Anakan waters, Cilacap. By: Isnani Herianti and Duto Nugroho

The biological investigation of eel resources have been conducted in Segara Anakan waters, Cilacap District. This study describes the size distribution and variation of its reproductive activity. The reproductive performances were analyzed through cross section of gonad using paraffin method and stained with hematoxylin ehrlich-eosin to the sample that are considered to represent group of length. The result showed that the length frequency are the typically bimodal distribution with tendencies of differences in size based on seasons. The seasonly average length showed a significantly different $(P<0.01)$. Variation in reproductive activity as part of biological indicator of exploitation level showed some differences level of gonad development stages, starting from unidentified, undevelop, until toward mature gonadal levels.

KEYWORDS: $\quad$ eel, catches distribution, reproduction aspect, Segara Anakan

\section{PENDAHULUAN}

Ikan sidat (Anguilla bicolor bicolor McClelland, 1844) digolongkan sebagai ikan liar yang dieksploitasi dalam skala kecil oleh para penangkap ikan di habitat perairan umum. Di kawasan Indo-Pasifik telah terpetakan siklus hidup dan struktur phylogenetika dari sejumlah 11 spesies Anguilla (Aoyama, 2009). Mengacu pada pola ruayanya kelompok jenis ikan sidat termasuk dalam kategori ruaya katadromous di mana habitat sangat berkaitan erat dengan perkembangan tingkat morphologi pada siklus hidupnya. Pada tingkat juvenile banyak ditemukan di kawasan estuaria, sungai, dan danau sedangkan pada tahapan pemijahan akan beruaya ke kawasan lepas pantai atau samudera dengan kadar salinitas yang tinggi (Tesc, 1997; 2003; dalam Aoyama, 2009).
Pemanfaatan secara komersial dilakukan teknik yang sangat sederhana di mana alat tangkap yang digunakan adalah alat tradisional yang bersifat pasif yaitu pancing urek dengan umpan kepiting air tawar dilakukan pada pagi atau siang hari, dan pancing opyok dengan umpan cacing, dilakukan pada malam hari. Kedua alat tangkap tersebut masuk dalam katagori lain-lain karena agak sulit digolongkan dalam katagori alat tangkap sesuai standarisasi alat tangkap yang baku. Pancing urek terbuat dari seutas senar dengan panjang $\pm 0,5-0,75 \mathrm{~m}$, pada ujungnya dipasang mata pancing berkait sedangkan pancing opyok terdiri atas joran yang terbuat dari kayu dengan panjang $\pm 1,0$ $1,5 \mathrm{~m}$, pada ujungnya diikatkan tali atau benang kasur untuk merangkai cacing sebagai umpan. Terbatasnya seri data dan informasi pemanfaatan menyebabkan kesulitan dalam memberikan indikator status sumber 
daya ikan sidat, sehingga pembahasan lebih ditekankan pada karakteristik bio reproduksi berdasarkan atas perbedaan musim.

Lagler et al. (1977); Deelder (1984) mengatakan bahwa pada umumnya ikan sidat hanya memijah sekali dalam hidupnya kemudian mati setelah berlangsungnya proses pemijahan. Kontinuitas aktivitas penangkapan yang dilakukan sepanjang tahun menimbulkan kekhawatiran punahnya sumber daya ikan sidat karena tingginya mortalitas pada saat ruaya menuju laut lepas untuk berpijah.

Tingginya permintaan pasar terhadap jenis ini dan terbatasnya sediaan alam menyebabkan berkembangnya teknik pembesaran melalui kegiatan budi daya secara intensif. Untuk mendukung usaha tersebut diperlukan informasi dasar khususnya mengenai aspek reproduksinya dan sampai saat ini belum banyak penelitian reproduksi ikan sidat yang dapat diacu sebagai dasar untuk budi daya pembenihan. Hal ini mengingat tingkat kesulitannya yang tinggi antara lain perilaku ikan sidat sebagai catadromous migrant yang memijah di laut pada kedalaman $\pm 250 \mathrm{~m}$ (Deelder, 1984).

Perkembangan gonad merupakan bagian dari biologi reproduksi yang penting diketahui khususnya untuk ikan dengan tingkat keterancaman punah sangat tinggi. Mengetahui ukuran panjang ikan pada saat pertama kali matang gonad dapat dijadikan dasar pengaturan penangkapan sebagai bagian dari upaya pengelolaan sumber daya ikan tersebut. Penelitian ini bertujuan untuk mengetahui ukuran dan sebaran hasil tangkapan nelayan, serta aspek reproduksi sebagai bagian dari pemetaan status pemanfaatan ikan sidat di perairan Segara Anakan, Cilacap. Temuan ini diharapkan dapat menjadi salah satu pertimbangan bagi pengelolaan dan keberlanjutannya sumber daya ikan sidat maupun sebagai salah satu acuan untuk pengembangan budi daya dalam mendukung peningkatan produksi ikan dalam skala wilayah maupun nasional.

\section{BAHAN DAN METODE}

\section{Bahan Penelitian}

Bahan yang digunakan adalah ikan sidat hasil tangkapan nelayan berukuran panjang 30-92 cm, beberapa bahan kimia antara lain larutan bouin sebagai fiksatif, toluo/sebagai penjernih, dan alkohol berbagai konsentrasi sebagai dehidran. Alat yang digunakan antara lain disecting apparatus, timbangan Acculab V-400, mikroskop cahaya Olympus, mikrometer okuler, kamera Olympus BHB, rotary microtome, dan beberapa peralatan gelas.

\section{Metode Penelitian}

Penelitian dilaksanakan dari mulai bulan September 2004 sampai Mei 2006. Untuk menduga sebaran ukuran panjang ikan dilakukan pengambilan contoh terhadap hasil tangkapan nelayan pada musim penghujan dan kemarau, selanjutnya dianalisis untuk mengetahui perbedaan antara keduanya. Ikan contoh kemudian diukur panjang dan bobotnya, dibedah untuk diambil dan ditimbang bobot gonad, hepar maupun organ viceralnya. Pembuatan preparat histologi gonad dilakukan dengan metode parafin (Handari, 1983). Untuk mewarnai inti dan sitoplasma sel digunakan metode pewarnaan hematoxylin ehrlich-eosin. Preparat histologis gonad selanjutnya diamati di bawah mikroskop dengan perbesaran 100 dan 400 kali. Pengukuran diameter folikel ovarium dilakukan secara acak terhadap sejumlah 50 folikel yang nukleusnya terlihat dengan jelas menggunakan mikrometer okuler (Pankhurst, 1982a).

\section{Analisis Data}

Untuk mengetahui perbedaan rata-rata ukuran panjang ikan hasil tangkapan nelayan pada musim penghujan dan kemarau, digunakan uji-t (Steel \& Torrie, 1995). Sedangkan untuk memprediksi aktivitas reproduksi dilakukan penghitungan indeks gonado somatik, indeks hepato somatik, dan indeks visero somatik yang merupakan rasio bobot gonad, hepar, maupun organ viceral terhadap bobot ikan. Faktor kondisi dihitung berdasarkan atas data bobot dan panjang total ikan (TL) dengan persamaan: $\mathrm{FK}=\left(\mathrm{Wg} \times 10^{2}\right) \times(\mathrm{TL} \mathrm{cm})^{-3}$.

\section{HASIL DAN BAHASAN}

\section{Ukuran dan Sebaran Hasil Tangkapan}

Hasil pengambilan contoh ikan sidat hasil tangkapan nelayan di perairan Segara Anakan menggunakan pancing opyok pada musim penghujan berkisar antara panjang 30,0-72,0 cm (panjang ratarata 44,1 $\pm 7,37 \mathrm{~cm}$ ). Sedangkan pada musim kemarau menggunakan pancing urek berkisar antara panjang $36,0-80,0 \mathrm{~cm}$ (panjang rata-rata 64,6 $\pm 6,08 \mathrm{~cm}$ ). Hasil analisis lebih lanjut menunjukan bahwa rata-rata ukuran ikan sidat hasil tangkapan berdasarkan atas musim berbeda sangat nyata $(P<0,01)$. Gambar 1 menampilkan sebaran frekuensi panjang ikan sidat di Segara Anakan. Analisis grafis memperlihatkan bahwa sebaran ukuran panjang ikan yang tertangkap mempunyai dua modus kelompok panjang. 


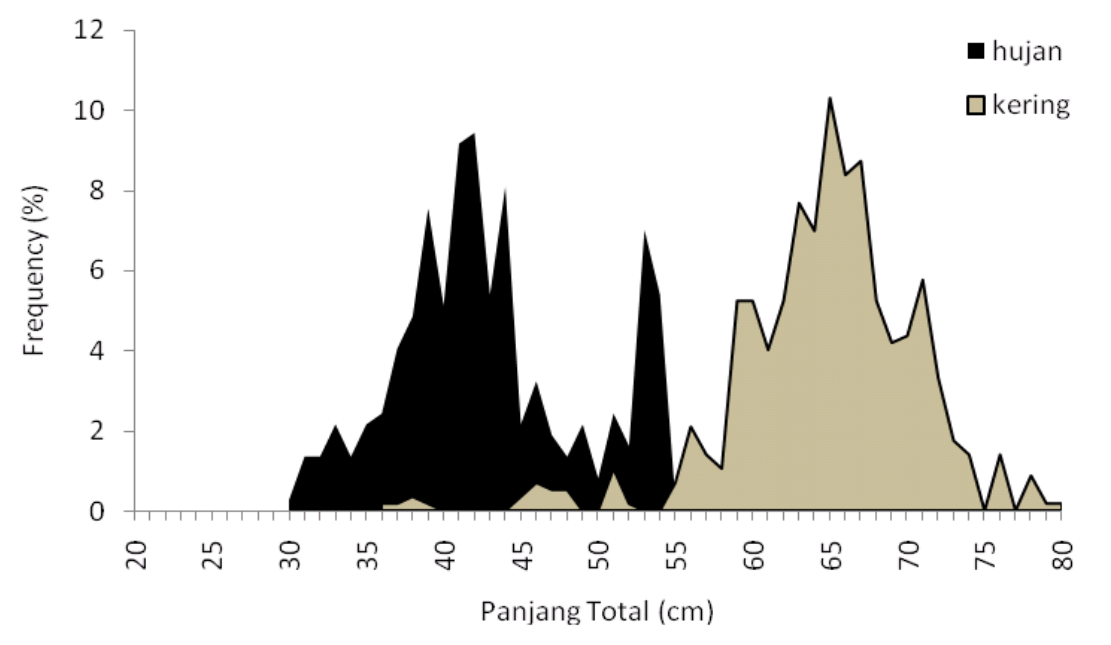

Gambar 1. Sebaran frekuensi panjang.

Figure 1. Length frequency distribution.

Perbedaan modus hasil tangkapan lebih disebabkan karena cara tangkap yang berbeda. Pada musim kemarau nelayan lebih mudah untuk menentukan ukuran sasaran hasil tangkapan ketimbang pada musim penghujan yaitu dengan mengenali lubang-lubang persembunyian ikan. Sementara pada musim penghujan air menggenangi lubang persembunyian ikan sidat sehingga penangkapan dilakukan di atas perahu di daerah hunian ikan sidat. Nelayan pada umumnya tidak melakukan penangkapan terhadap ikan sidat berukuran kecil. Tujuan penangkapan adalah ikan sidat berukuran besar sesuai permintaan pasar yaitu pada ukuran $>50 \mathrm{~cm}$.

\section{Diferensiasi dan Perkembangan Gonad}

Ikan sidat mempunyai siklus hidup yang terdiri atas beberapa tahapan atau fase dimulai dari induk ikan sidat matang gonad berwarna keperakan (silver eel) yang akan beruaya dari perairan tawar ke laut atau perairan asin, mencari daerah pemijahan. Setelah memijah induk ikan sidat mati dan telur ikan sidat menetas menjadi individu kecil berbentuk pipih transparan disebut leptocephalus (Deelder, 1984). Dalam proses perkembangan selanjutnya leptocephalus mengalami metamorfose berbentuk ikan sidat kecil transparan (glass eel), berukuran antara 39-50 mm (Tesch, 1977). Pada fase ini ikan sidat kecil sudah mencapai perairan pantai. Selanjutnya ruaya ikan sidat diteruskan dan bergerak memasuki sungai. Pada saat memasuki sungai dimulai proses pigmentasi, menjadi ikan sidat muda berwarna kecoklatan (elver) dan beruaya menuju ke hulu sungai, tumbuh menjadi ikan sidat dewasa belum matang gonad berwarna coklat kekuningan (yellow eel). Selanjutnya ikan sidat dewasa setelah matang gonad berwarna keperakan (silver eel) akan beruaya kembali ke laut untuk memijah.

Hasil identifikasi, ikan sidat hasil tangkapan nelayan semuanya adalah jenis Anguilla bicolor bicolor dalam fase yellow eel dengan warna tubuh coklat kehijauan pada bagian dorsal dan putih pucat sampai putih kekuningan pada bagian ventral. Hasil pengamatan melalui pembedahan, ikan sidat ukuran panjang $<30-40 \mathrm{~cm}$ sulit diidentifikasi jenis kelaminnya. Pembuatan preparat mikroanatomi dilakukan pada beberapa ikan betina berukuran panjang antara 40-72 cm yang dianggap mewakili kelompok ukuran panjang ikan hasil tangkapan.

Penampang lintang gonad ikan sidat betina berbagai ukuran yang mencerminkan keragaan aktivitas reproduksi sumber daya ikan sidat di Segara Anakan ditampilkan pada Gambar 2. Rata-rata diameter oosit ikan sidat berkisar antara 0,039 $\pm 0,0099$ $\mathrm{mm}$ sampai 0,099 $\pm 0,0173 \mathrm{~mm}$. Menurut Wallace \& Selman (1990) dalam Takashima (1995), bahwa pertumbuhan ovarium ikan secara umum dikelompokan dalam enam fase perkembangan yang dicirikan oleh perkembangan oosit di dalamnya yaitu fase kromatin-nukleolus, perinukleolar, kortikal-alveoli, vitelogenik, maturasi, dan ovulasi.

Kondisi gonad yang belum berkembang terlihat pada ikan berukuran $40-44 \mathrm{~cm}$ dalam fase kromatin nukleolus dengan diameter oosit 0,0390 $\pm 0,0099 \mathrm{~mm}$. Gonad yang lebih berkembang selain terlihat dari ukuran diameter oosit $(0,0590 \pm 0,0123 \mathrm{~mm})$ juga terlihat ada beberapa folikel dengan nukleolus lebih dari satu. Gambaran ini terlihat pada spesimen berukuran panjang $52-53 \mathrm{~cm}$, dalam fase kromatin nukleolus, sedangkan pada ukuran $60-62 \mathrm{~cm}$ diameter 
oositnya sudah lebih besar $(0,076 \pm 0,0111 \mathrm{~mm})$ dengan status gonad sudah memasuki fase perinukleolar awal. Sementara spesimen berukuran $63-72 \mathrm{~cm}$ dengan diameter 0,099 $\pm 0,0173 \mathrm{~mm}$ mempunyai gonad dalam fase perinukleolar yang ditandai adanya nukleus dengan beberapa nukleoli di bagian tepi nukleoplasma dan mulai terlihat lebih banyak ruang sitoplasmik yang mengindikasikan adanya lipid di dalamnya.
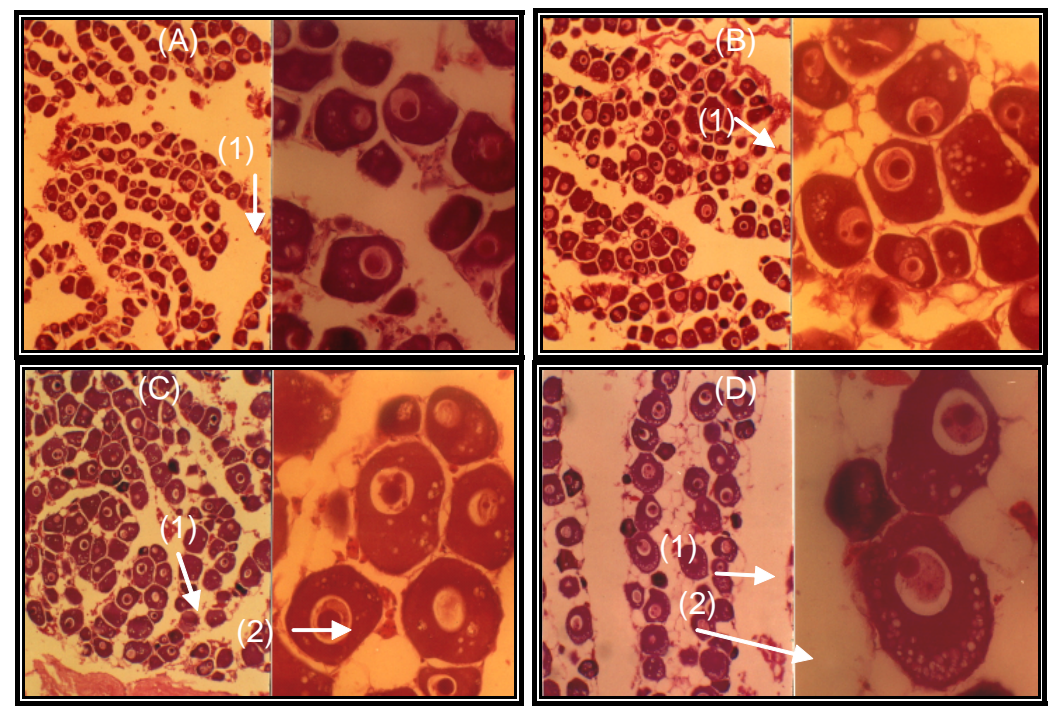

Gambar 2. Penampang lintang gonad ikan sidat di perairan Segara Anakan. (A) ukuran panjang total ikan $44 \mathrm{~cm} /$ diameter oosit 0,039 $\pm 0,0099 \mathrm{~mm}$, (B) ukuran panjang $53 \mathrm{~cm} /$ diameter oosit

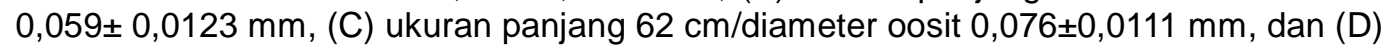

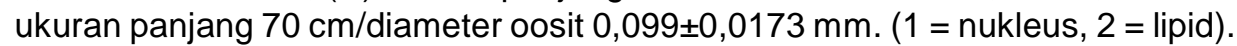

Figure 2. Cross section gonad of eel in Segara Anakan waters. (A) total length $44 \mathrm{~cm} /$ oocyte diameters $0.039 \pm 0.0099 \mathrm{~mm},(B)$ total length $53 \mathrm{~cm} /$ oocyte diameters $0.059 \pm 0.0123 \mathrm{~mm}$, (C) total length $62 \mathrm{~cm} /$ oocyte diameter $0.076 \pm 0.0111 \mathrm{~mm}(D)$ total length $70 \mathrm{~cm} /$ oocyte diameter $0.099 \pm 0.0173 \mathrm{~mm}$ (1 = nucleus, 2 = lipid $)$.

Menurut Sinha \& Jones (1975) dalam Pankhurst (1982b), apabila ikan sidat mempunyai oosit dengan diameter $<0,10 \mathrm{~mm}$ termasuk dalam katagori sexually immature adult dan bila mempunyai oosit dengan diameter $>0,10 \mathrm{~mm}$ dikatagorikan sebagai sexually maturing adult. Mengacu pada kriteria tersebut ternyata ikan sidat yang tertangkap di perairan Segara Anakan dalam katagori betina belum matang kelamin. Menurut Takashima (1995), oosit pada fase perinukleoler baru mulai mengalami deferensiasi. Dengan demikian fase perinukleolar merupakan fase awal perkembangan oosit.

Tesch (1977) menginformasikan bahwa secara natural ikan sidat memijah di laut pada salinitas tinggi ( $>30$ ppt). Sementara Querat et al. (1982) mengatakan bahwa ikan sidat ketika akan beruaya mijah ke laut mempunyai oosit dalam tahap profase pada awal pembelahan meiotik, perkembangan gonad lebih lanjut terjadi ketika ikan sidat berada pada lingkungan perairan dengan salinitas yang tinggi.

Pada proses maturasi terjadi perubahan warna kulit pada ikan sidat, yang semula berwarna coklat hijau di bagian dorsal dan putih kekuningan di bagian ventral, berubah menjadi lebih gelap, dan mengkilat keperakan setelah matang gonad (Pankhurst, 1982b). Pankhurst \& Lythgoe (1982) mengatakan bahwa perubahan warna keperakan pada umumnya digunakan untuk membedakan ikan sidat dewasa matang kelamin dengan dewasa belum matang kelamin atau dari fase yellow eel ke fase silver eel. Selama penelitian berlangsung tertangkap seekor ikan sidat (oleh jaring apong) sebobot $1.450 \mathrm{~g}$. dan panjang total $92,0 \mathrm{~cm}$. Ikan tersebut telah memasuki fase silver eel, dikenali dari kulitnya yang berwarna mengkilat keperakan. Dari pengamatan penampang lintang gonadnya terlihat mempunyai diameter oosit 0,1944 $\pm 0,0333 \mathrm{~mm}$ artinya ikan sudah masuk dalam katagori dewasa matang kelamin. Gambaran besarnya ruang sitoplasmik folikel ovarium mengindikasikan terjadinya fusi butir-butir lipid di dalamnya. Selain itu terlihat adanya disintegrasi dari dinding nukleus (Gambar 3). Kondisi ini menunjukan tingkat perkembangan gonad lebih lanjut (fase vitelogenik). 

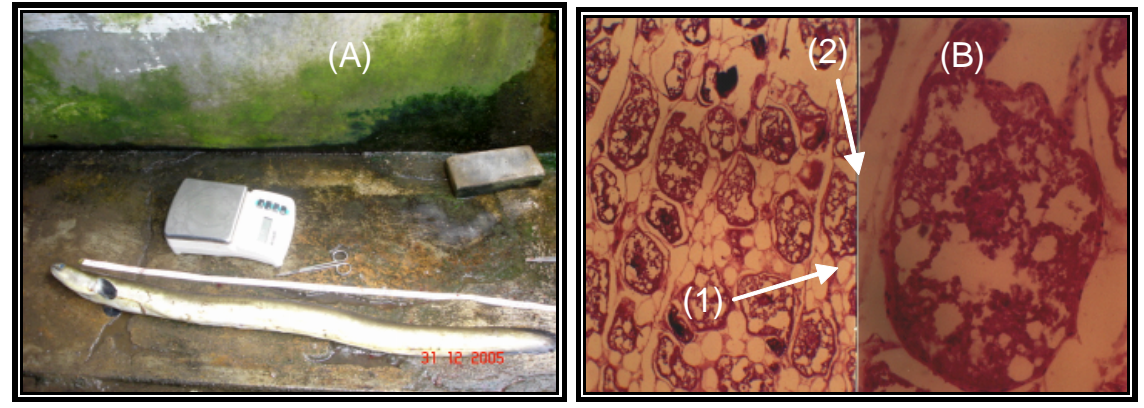

Gambar 3. (A) Ikan sidat hasil tangkapan jaring apong dan (B) penampang lintang gonad ( $1=$ fusi ruang sitoplasmik, 2 = dinding nukleus).

Figure 3. (A) Eel caught by apong net and (B) cross section of gonad, $(1=$ fusion of cytoplasmic space, 2 = nuclear wall).

\section{Indeks Gonado, Hepato, dan Vicero Somatik (IGS, IHS, IVS)}

Menurut De Vlaming et al. (1982) indeks gonado somatik merupakan indeks kesiapan pemijahan, dengan demikian meningkatnya nilai indeks gonado somatik sejalan dengan meningkatnya diameter telur. Bobot gonad ikan sidat pada penelitian ini berkisar antara 0,2-6,7 g pada kisaran panjang $40-72 \mathrm{~cm}$, sementara pada ukuran panjang $32-39 \mathrm{~cm}$ belum dapat diidentifikasi. Hasil penghitungan indeks gonado somatik ikan sidat betina yang tertangkap di perairan Segara Anakan berkisar antara 0,2004-1,1687\%.
Gambar 4 menampilkan keragaan nilai indeks gonado somatik ikan sidat dalam satuan persen dan bobot gonad dalam satuan gram di lokasi penelitian. Nilai indeks gonado somatik cenderung meningkat dengan bertambahnya ukuran panjang ikan di mana hal ini didukung oleh gambaran mikroanatomi gonad. Semakin besar nilai indeks gonado somatik makin tinggi aktivitas reproduksi yang dicirikan dengan meningkatnya diameter oosit dan perkembangan gonad menuju tahap lebih lanjut. Variasi nilai indeks gonado somatik menunjukan keragaan aktivitas reproduksi sumber daya ikan sidat di perairan Segara Anakan.

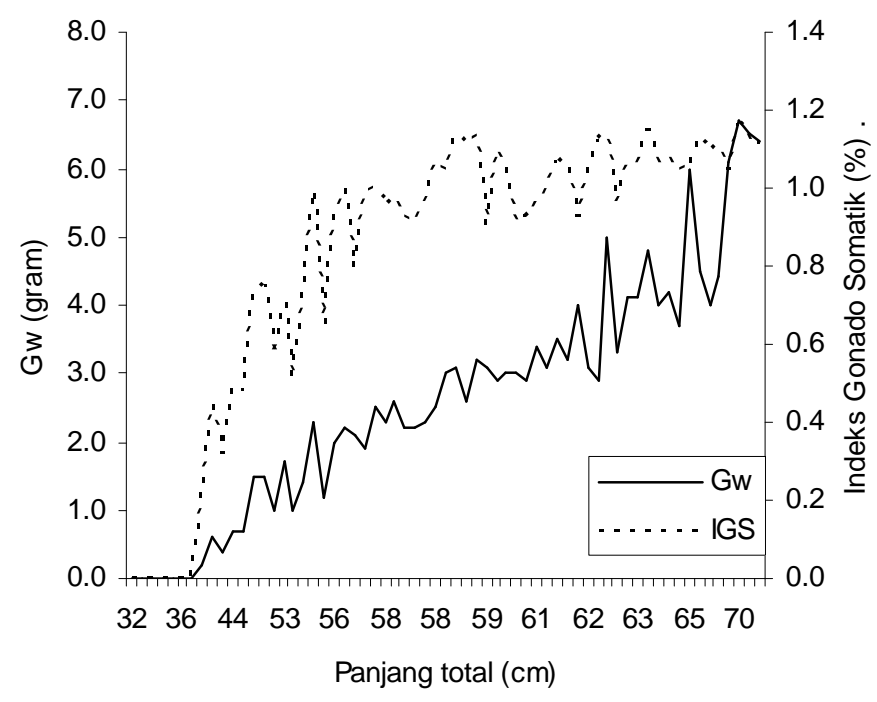

Gambar 4. Keragaan indeks gonado somatik menurut ukuran panjang ikan.

Figure 4. Variation of gonado somatic index by length distribution of fish.

Bobot hepar ikan sidat pada penelitian ini berkisar antara 0,3-6,0 g. Nilai indeks hepato somatik ikan sidat hasil tangkapan berkisar antara 0,6048$1,0453 \%$. Terlihat kecenderungan kenaikan nilai indeks hepato somatik sejalan dengan meningkatnya ukuran panjang ikan (Gambar 5). Indeks hepato somatik merupakan besaran yang berhubungan dengan deposisi lipid di dalamnya. Aktivitas hepar dapat diketahui dari besarnya nilai indeks hepato somatik, hal ini tergantung dari jenis kelamin, musim, 
umur, dan kondisi fisiologis yang berkenaan dengan makanan, reproduksi atau stres. Tienhoven (1983); Persson et al. (1998) mengatakan bahwa gonad dan hepar merupakan organ yang berperan penting dalam reproduksi, pada proses vitelogenesis yaitu pembentukan vitelogenin sebagai prazat (precursor) kuning telur (yolk) pada ikan (fase vitelogenik eksogenus dan endogenus). Oleh karena itu indeks hepato somatik akan meningkat selama proses pematangan gonad dan menurun setelah terjadi pemijahan. Pada penelitian ini nilai indeks hepato somatik mempunyai kecenderungan meningkat artinya proses pematangan gonad sedang berlangsung. Hal ini didukung pula oleh meningkatnya nilai indeks gonado somatik ikan.

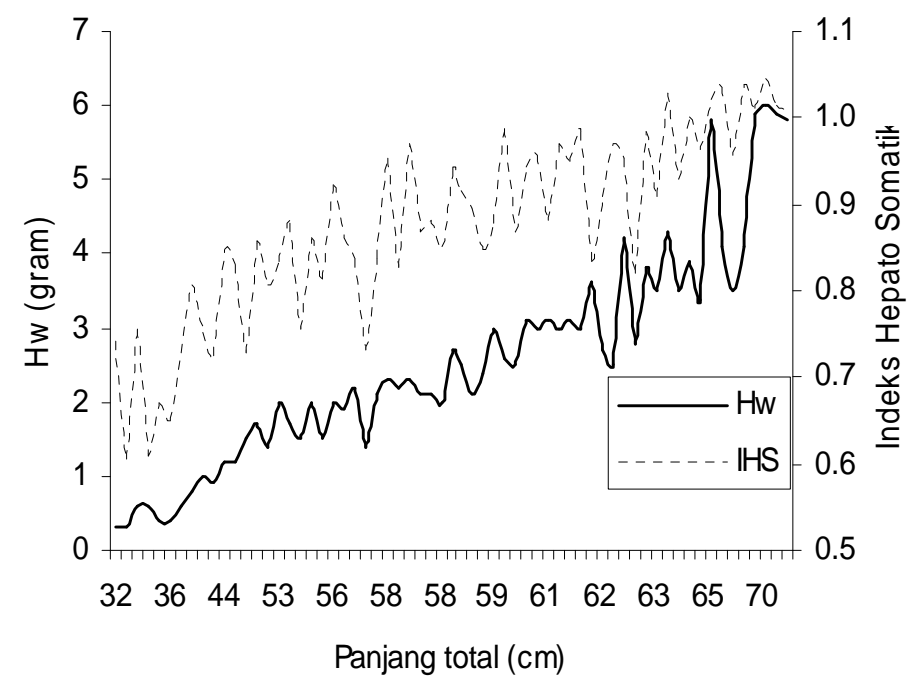

Gambar 5. Hubungan bobot hepar dan indeks hepato somatik berdasarkan atas ukuran panjang ikan. Figure 5. Relationship between weight of hepar and variation of hepato somatic index by length distribution of fish.

Barni et al. (1985) dalam Brusle \& Anadon (1996) mengatakan bahwa hepar ikan sidat pada fase yellow ee/ mengandung banyak glikogen sedangkan pada fase silver eel mengandung banyak lipid. Glikogen diperlukan sebagai cadangan energi selama perkembangan gonad. Nielsen (1990) mengatakan bahwa energi yang diperoleh dari oksidasi $1 \mathrm{~g}$ lemak kira-kira dua kali lebih tinggi ketimbang oksidasi $1 \mathrm{~g}$ karbohidrat atau protein, sehingga dapat dipahami adanya dua bentuk cadangan energi pada ikan sidat. Pada fase silver eel ikan mempersiapkan diri melakukan ruaya mijah ke laut dalam, tanpa makan sampai akhir proses pemijahan berlangsung dan mati kemudian. Hal ini juga ditegaskan oleh Tesch (1977) bahwa untuk keberhasilan ruaya menuju spawning ground ikan sidat memerlukan cadangan energi yang cukup besar karena selama perjalanan ruaya, ikan sidat tidak melakukan aktivitas makan. Boetius \& Boetius (1982) menghitung sekitar $18 \%$ total energi yang disimpan digunakan untuk perkembangan gonad, $27 \%$ untuk metabolisme selama proses maturasi, $30 \%$ untuk ruaya mijah, dan $25 \%$ sisanya untuk melangsungkan pemijahan. Svedang \& Wickstrom
(1997) mengatakan bahwa ikan sidat mempunyai kemampuan untuk menunda proses maturasi dan melanjutkan fase penggemukan (fattening) bila dirasa cadangan tenaga untuk ruaya mijah kurang mencukupi $(<20 \%)$.

Bobot organ visceral ikan sidat pada penelitian ini berkisar antara 2,5-22,5 g. Keragaan indeks vicero somatik ikan sidat berkisar antara 3,23-6,53\%. Kebalikan dengan nilai indeks gonado somatik dan indeks hepato somatik, nilai indeks vicero somatik cenderung menurun sejalan dengan bertambahnya ukuran ikan (Gambar 6). Menurut Sulistyo (2005) ketika gonad dalam kondisi istirahat nilai indeks gonado somatik cenderung rendah sementara nilai indeks vicero somatik dalam keadaan maksimum. Hal ini berkaitan dengan periode aktif makan pada ikan, bahwa ketika aktivitas gonad berkurang maka ikan akan menimbun makanan dalam bentuk lemak di sekitar organ viceral. Sebaliknya ketika aktivitas reproduksi berlangsung ikan akan makan secara pasif. 


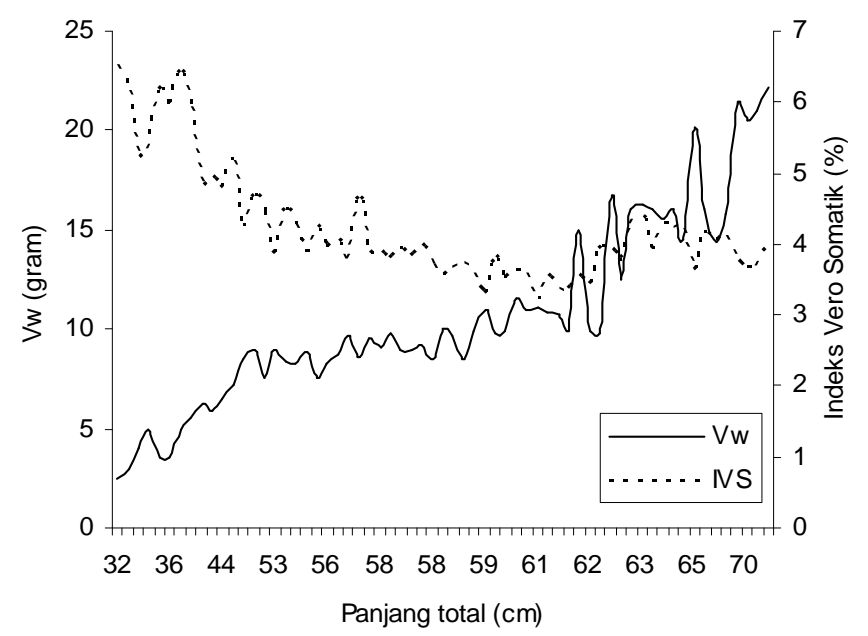

Gambar 6. Hubungan bobot organ viceral dan indeks vicero somatik dan ukuran panjang ikan.

Figure 6. Relationship betwwen weight of viceral organ and variation of vicero somatic index by length distribution of fish .

Jika memperhatikan Gambar 6, terlihat kecenderungan peningkatan nilai indeks vicero somatik pada ikan berukuran $63 \mathrm{~cm}$. Fakta ini menimbulkan asumsi bahwa aktivitas makan ikan sidat pada fase yellow eel meningkat kembali menjelang ikan memasuki fase silver eel. Pada masa ini dikatakan sebagai fase penggemukan. Menurut Dave et al. (1975) dalam Svedang \& Wickstrom (1997), fase penggemukan dilakukan untuk menimbun lemak di dalam muskulus dan hepar sebagai cadangan tenaga selama perjalanan ruaya mijah ke laut, kemudian ikan akan berhenti makan pada fase silver eel (Pankhurst \& Sorensen, 1984).

\section{Faktor Kondisi}

Pada dasarnya faktor kondisi dapat digunakan untuk mengetahui pertumbuhan gonad karena nilainya dihitung berdasarkan atas panjang dan bobot ikan berkaitan dengan kesuburan perairan. Parsons et al. (1977) mengatakan bahwa penurunan nilai faktor kondisi pada ikan sidat di suatu perairan mengindikasikan rendahnya ketersediaan pakan yang dibutuhkan untuk pertumbuhannya. Pada penelitian ini dihitung nilai faktor kondisi dan nilai faktor kondisi tanpa memasukan bobot gonad (FK-tg) untuk melihat aktivitas perkembangan gonad dalam populasi. Nilai masing-masing yang diperoleh berkisar antara 0,10420,2295 (untuk faktor kondisi) dan 0,1032-0,2069 (untuk FK-tg). Kecilnya selisih nilai keduanya menunjukan lambatnya perkembangan gonad ikan dalam populasi tersebut. Variasi nilai faktor kondisi dan FK-tg ikan sidat pada penelitian ini disajikan pada Gambar 7.

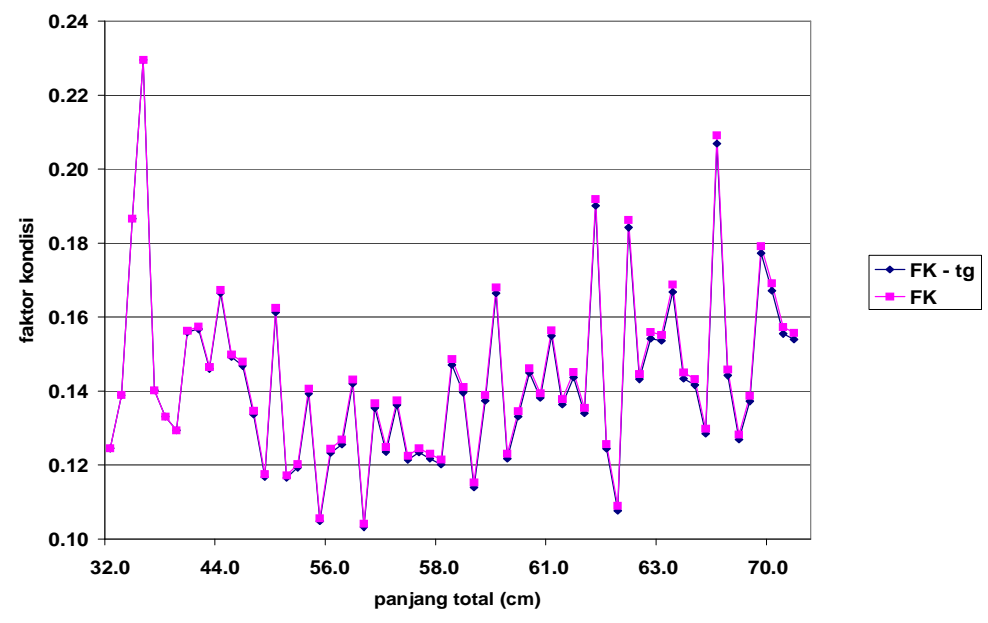

Gambar 7. Keragaan nilai faktor kondisi berdasarkan atas sebaran ukuran panjang ikan. Figure 7. Variation of condition factor by length distribution of fish. 
Pada Gambar 7 terlihat bahwa aktivitas reproduksi dalam populasi ikan sidat di perairan Segara Anakan sangat lambat, hal ini disebabkan oleh:

1. Ikan yang tertangkap dalam fase yellow eel, belum matang kelamin baik dilihat secara morfologi maupun secara mikroanatomi.

2. Alat tangkap yang digunakan mempunyai peluang yang kecil untuk menangkap ikan sidat fase silver eel, ketika ikan tidak lagi melakukan aktivitas makan, mengabaikan umpan yang dipasang oleh nelayan.

3. Pematangan gonad fase lanjut terjadi pada saat ikan beruaya ke laut menuju daerah pemijahan.

4. Sidat merupakan ikan yang lambat pertumbuhannya artinya tahap maturasi juga berlangsung secara lambat ketika menghuni perairan tawar.

Satu-satunya contoh ikan sidat fase silver ee/yang diperoleh pada penelitian ini merupakan ikan hasil tangkapan sampingan (bycatch) dari jaring apong. Tidak dijumpai ikan dalam status perkembangan gonad lebih lanjut pada ikan hasil tangkapan alat utama yang digunakan nelayan untuk menangkap ikan sidat di perairan ini, terbukti tergolong ikan muda.

Tesch (1977) mengatakan bahwa secara alami untuk metamorfose ke stadium ruaya mijah ikan sidat betina (Anguilla anguilla) paling tidak telah mencapai critical length yaitu panjang yang dicapai untuk memasuki tahap dari yellow eel menjadi silver eel (ukuran panjang 50-60 cm) pada umur 9-12 tahun. Hal ini berkaitan dengan dicapainya kandungan lemak yang cukup untuk proses maturasi lebih lanjut. Ditegaskan juga oleh Nikolskii (1969) bahwa maturasi sangat ditentukan oleh kondisi lingkungan terutama makanan, meski demikian menurut Svedang et al. (1996) bahwa maturasi tidak hanya ditentukan oleh faktor lingkungan yang mempengaruhi pertumbuhan, dan panjang saat memasuki metamorfosis atau critical length berkaitan dengan jarak menuju daerah pemijahan. Critical length dikendalikan secara genetis dan bervariasi antar jenis atau ras. Hasil pengamatan pada penelitian ini baik secara visual maupun mikroskopis gonad, ikan sidat dengan panjang $72 \mathrm{~cm}$ dalam fase dewasa belum matang kelamin atau yellow eel. Hal ini diduga berkaitan dengan jauhnya jarak daerah pemijahannya. Tesch (1977) memberikan informasi bahwa daerah pemijahan ikan sidat diperkirakan berada di perairan selatan barat Sumatera, berdasarkan atas banyaknya leptocephali yang tertangkap di kedalaman $300 \mathrm{~m}$ pada suhu $12^{\circ} \mathrm{C}$. Sementara menurut L'abee Lund (1994) bahwa laju pertumbuhan ikan catadromus ketika berada di air tawar sangat kecil pengaruhnya terhadap kematangan gonad dan sebaliknya laju pertumbuhan ketika berada di air asin berpengaruh secara signifikan. Terdapat indikasi adanya keseimbangan hubungan dan interaksi antar berbagai sistem fisiologis dalam proses pertumbuhan yang lambat, diferensiasi dan pematangan gonad pada ikan sidat.

\section{KESIMPULAN}

1. Sebaran ukuran hasil tangkapan mempunyai dua modus panjang dengan kecenderungan yang berbeda nyata pada musim hujan $(44,1 \mathrm{~cm})$ dan musim kemarau $(64,6 \mathrm{~cm})$ dengan aktivitas penangkapan cenderung lebih tinggi pada musim penghujan.

2. Aktivitas reproduksi ikan sidat pada ukuran $30-80$ $\mathrm{cm}$ mempunyai kisaran tingkat kematangan gonad pada tingkatan yang belum teridentifikasi (unidentified), belum berkembang (undevelop) sampai tahap menuju matang gonad.

3. Indikator diferensiasi gonad yang ditunjukan oleh indeks gonado somatik dan diperjelas oleh gambaran struktur histologis gonad mengindikasikan bahwa ikan sidat yang terangkap berada pada proses berlangsungnya kematangan gonad dengan ukuran rata-rata $64,6 \mathrm{~cm}$ dalam proses awal kematangan gonad.

4. Pemanfaatan sumber daya ikan sidat di perairan Segara Anakan yang berlangsung secara terusmenerus sepanjang tahun pada ukuran dengan tingkat belum matang gonad yang dilakukan dengan bantuan alat tangkap tradisional dalam skala harian perlu dilakukan dengan memperhatikan aspek kehati-hatian mengingat calon induk yang akan beruaya ke perairan laut lepas mengalami kematian akibat penangkapan untuk memenuhi kebutuhan pasar yang cenderung semakin tinggi.

5. Penentuan kawasan lindung terhadap ukuran ikan sidat menjelang ruaya untuk berpijah perlu dilakukan untuk menjamin kelangsungan proses rekruitmen dalam siklus hidupnya.

\section{PERSANTUNAN}

Tulisan ini merupakan kontribusi dari kegiatan riset kelautan dan perikanan, T. A. 2004 dan 2005, di Pusat Riset Perikanan Tangkap-Ancol, Jakarta. 


\section{DAFTAR PUSTAKA}

Aoyama, J. 2009. Life history and evolution in migration in Catadromous eels (genus Anguilla). Aqua-BioSci. Monogr. Terrapub. Tokyo. 2 (1): 142.

Boetius, I. \& J. Boetius. 1982. Experimental maturation of european Silver eels. Proceeding of the International Symposium on Reproductive Physiology of Fish. (edited by C. J. J. Reichter \& H. J. Goos). Centre for Agricultural Publishing \& Documentation. Wageningen. 174-176.

Brusle, J. \& G. G. I. Anadon. 1996. The structure and function of fish liver. In Fish Morphology. Horizon of New Research (edited by J. S. Datta Munshi \& H. M. Dutta). Science Publisher Inc. USA. 77-93.

Deelder, C. L. 1984. Synopsis of Biological Data on the Eel Anguilla anguilla (Linneaus, 1958). FAO. Rome. 1-59.

De Vlaming, V., G. Grossman, \& F. Chapman. 1982. On the use of gonosomatic indx. Comp. Biochem. Physiol. 73A: 31-39.

Handari, S. S. 1983. Metode Pewarnaan (Histologi dan Histokimia). Bhratara Karya Aksara. Jakarta. 17-184.

L' abee Lund, J. H. 1994. Effect on smolt age, sex, and environmental condition on sea age at first maturity of anadromous brown trout Salmo trutta in Norway. Aquaculture. (121): 65-71.

Lagler, K. F., J. E., Bardach, R. R., Miller, \& D. R. M., Passino. 1977. Ichtyology. John Willey and Sons. Inc. New York-London-England. 506 pp.

Nikolskii, G. V. 1969. Fish Population Dynamics. Oliver and Brys. Edinburg. 323 pp.

Nielsen, K. S. 1990. Energy metabolism. In Animal Physiology. Adaptation and Environment. Cambridge University Press. USA. 169-214.

Pankhurst, N. W. 1982a. Relation of visual changes to the onset of sexual maturation in the European Eel, Anguilla anguilla (L). J. Fish. Biol. (21): 127140.

Pankhurst, N. W. 1982b. Changes in the skin scale complex with sexual maturation in the European Eel, Anguilla anguilla (L). J. Fish. Biol. (21): 549561.
Pankhurst, N. W. \& J. H. Lythgoe. 1982. Structure and Colour of Integument of the European Eel, Anguilla anguilla (L). J. Fish. Biol. (21): 279-296.

Pankhurst, N. W. \& P. W. Sorensen. 1984. Degeneration of the alkimetary tract in sexually maturing European Anguilla anguilla (L) and American eels Anguilla rostrata (LeSueur). Canadian J. of Zool. (62): 1,143-1,149.

Parsons, J., K. U. Vickers, \& Y. Warden. 1977. Relationship between elver recruitment and changes in the sex ratio of silver eels Anguilla anguilla L. migrating from Lough Neagh, Nothern Ireland. J. Fish. Biol. (10): 211-229.

Persson, P., K. Sundell, B. T. H. Bjornsson, \& H. Lundquist. 1998. Calcium metabolism and osmoregulation during sexual maturation of river running Atlantic Salmon. J.Fish Biol.(52): 334-349.

Querat, B., J. L. Hatey, \& A. Hardy. 1982. Ovarian Steroid metabolism in the immature European Eel (Anguilla anguilla). Proceeding of the International Symposium on Reproductive Physiology of Fish. (Edited by C. J. J. Reichter \& H. J. Goos). Centre for Agricultural Publishing and Documentations. Wageningen. $112 \mathrm{pp}$.

Steel, R. G. D. \& J. H. Torrie. 1995. Prinsip dan prosedur statistika. Suatu Pendekatan Biometrik. Gramedia Pustaka Utama. 105-447.

Sulistyo, I. 2005. Indeks morfo-anatomi dan prediksi kinerja reproduktif ikan. Prosiding Seminar Nasional Biologi dan Akuakultur Berkelanjutan. Universitas Soedirman. Purwokerto. Tanggal 10 September 2005. 16-21.

Svedang, H., E. Neuman, \& H. Wickstrom. 1996. Maturation pattern in female eel: Age and size at the silver eel stage. J. Fish. Biol. (48): 342-351.

Svedang, H. \& H. Wickstrom. 1997. Low fat contents in female Silver eel, indication of insufficient energitic stores for migration and gonadal development. J. Fish. Biol. (50): 475-486.

Takashima, F. 1995. Gonad. In An Atlas of Fish Hystology. Normal and Pathological Features. $2^{\text {nd }}$ Ed. (edited by Fumio Takashima \& T. Hibiya). Kodansha LTD. Tokyo. 128-153.

Tesch, F. W. 1977. The eel. Biology and Management of Anguillid Eels. Chapman and Hall Ltd. London. 1-240. 